JURNAL JENDELA HUKUM

ISSN Cetak \& Online : 2355-5831/2355-9934

\title{
KESADARAN HUKUM BERLALU LINTAS \\ KAITANNYA DENGAN PENEGAKAN HUKUM
}

\author{
Suryaningsih \\ Dosen Fakultas Hukum Universitas Wisnuwardhana Malang \\ surya.nings@yahoo.com
}

\begin{abstract}
ABSTRAK
Ketertiban lalu lintas di jalan raya merupakan sesuatu hal yang sama - sama kita dambakan, karena akhir - akhir ini lalu lintas di jalan raya kenyataanya merupakan "the killing field". Masalah lalu lintas semakin serius dan terus meningkat, hal ini dikarenakan kemajuan peradaban manusia serta kemajuan tehnologi yang demikian pesatnya. Kemajuan ini akan mendorong terbentuknya kota - kota besar, kota - kota metropolis dan mega polis yang tentu saja oleh suasana lalu lintas yang semakin rumit. Keadaan ini timbul bisa karena bermacammacam alasan antara lain, bertambahnya jumlah kendaraan bermotor termasuk kondisi kendaraanya, kondisi jalan yang kurang memenuhi syarat misalnya jalan rusak atau kurang lebar, penerapan peraturan yang kurang menggigit kepada para pengguna jalan raya atau masyarakat, kurangnya kesadaran para pengemudi mematuhi peraturan lalu lintas dan rendahnya etika dalam berlalu lintas di jalan raya. Ada beberapa factor yang mempengaruhi kesadaran hukum berlalu lintas. Diantara factor itu factor manusialah yang paling menonjol sebagai penyebab terjadinya kecelakaan. Untuk mengurangi hal itu perlu peningkatan kesadaran hukum beralalu lintas, baik sebagai pengemudi maupun sebagai pejalan kaki. Disamping kesadaran hukum, penegakkan hukum juga sangat diperlukan untuk mewujudkan adanya tertib berlalu lintas di jalan raya.
\end{abstract}

Kata Kunci : Kesadaran Hukum, Penegakan Hukum dan Lalu Lintas. 


\section{JURNAL JENDELA HUKUM}

ISSN Cetak \& Online : 2355-5831/2355-9934

\section{A. PENDAHULUAN}

Sejak UU No. 14 tahun 1992 tentang Lalu Lintas dan Angkutan Jalan Raya diundangkan dan berlaku secara efektif tanggal 17 September 1993 sudah kurang lebih 12 tahun berlaku di mayarakat. Pada kenyatanya dapat kita lihat di kota kota besar nampak ketidaktertiban masyarakat dalam berlalu lintas dan banyak sekali pelanggaran - pelanggaran yang dilakukan oleh penguna jalan. Keadaan ini timbul bisa karena bermacam-macam alasan antara lain, bertambahnya jumlah kendaraan bermotor termasuk kondisi kendaraanya, kondisi jalan yang kurang memenuhi syarat misalnya jalan rusak atau kurang lebar, penerapan peraturan yang kurang menggigit kepada para pengguna jalan raya atau masyarakat, kurangnya kesadaran para pengemudi mematuhi peraturan lalu lintas dan rendahnya etika dalam berlalu lintas di jalan raya.

Dari beberapa factor yang menyebabkan ketidaktertiban berlalu lintas dan adanya pelanggaran lalu lintas, factor manusia atau pengguna jalan raya itu sendiri adalah merupakan faktor utama dan terpenting, terbukti di Malang saja pelanggaran terbanyak adalah tidak mempunyai Surat Ijin Mengemudi (SIM) dan melanggar rambu - rambu lalu lintas lainya. Disinilah kesadarn hukum masyarakat dalam berlalu lintas dituntut untuk ditingkatkan.

Pembentuk Undan-undang lalu lintas meisyratkan bahwa adanya sanksi yang lebih berat bagi siapa saja melanggar peraturan ini, hal ini tidak dimaksudkan untuk membebani anggota masyarakat. Sanksi yang berat justru dimaksudkan sebagai upaya yang bersifat edukatif, artinya diarahkan untuk lebih mengembangkan disiplin dalam berlalu lintas bagi masyarakat. Sanksi yang berat itu sekaligus dimaksudkan bersifat preventif. (Robert Palandeng dkk, UU Lalulintas dan angkutan jalan, 1993, 71). Dengan ancaman sanksi yang berat seperti yang diatur Undang Undang Lalulintas tersebut Menteri Kehakiman Ismail Saleh waktu itu dengan sangat tangkas memberilkan penegasan bahwa ketentuan tersebut dimaksudkan untuk mendidik masyarakat untuk meningkatkan kesadaran hukumnya dengan mematuhi semua peraturan lalulintas. Menerapkan sanksi berat merupakan cara untuk memacu masyarkat agar dapat berperan serta dalam proses penegakan hukum yaitu Undang Undang No 14 tahun 1992 tentang Undang Undang Lalulintas dan Angkutan Jalan. Walaupun semua orang setuju yakni meningkatkan kesadaran hukum dan disiplin berlalulintas seharusnya tumbuh dan berkembang dari kesadaran setiap pemakai jalan raya, bukan karena paksaan ataupun dengan memperberat sanksi atau denda terhadap para pelanggar. (Harman, Undang Undang Lalulintas, 1993, 151).

Dalam sosiologis, pembuatan undang undang tidak dilihat sebagai kegiatan yang steril dan mutlak otonom. Dalam perspektif yang demikian itu, maka pekerjaan tersebut memiliki asal - usul sosial, tujuan sosial, mengalami intervensi sosial, mempunyai 
dampak sosial dan sebagainya. Dalam kata kata Jeremy Bentham, maka pembuatan undang - undang adalah suatu seni, yaitu seni untuk menemukan cara - cara untuk mewujudkan "the true good of the community" Bentham mematok "the greatest happiness of the community" sebagai tujuan yang harus diwujudkan melalui pembuatan undang undang dan dengan demikian mengkualifikasikan pekerjaan tersebut sebagai suatu aktivitas sosiologis. (Satjipto Rahardjo, 2004; 124)

Dengan berakhirnya pembuatan hukum, proses hukum baru menyelesaikan satu tahap saja dari suatu perjalanan panjang untuk mengatur masyarakat. Tahap pelaksanaan hukum masih harus disusul oleh pelaksanaannya secara konkrit dalam kehidupan masyarakat sehari - hari. Inilah yang dimaksud dengan penegakakan hukum.

Dalam stuktur Negara modern, maka tugas penegakkan hukum itu dijalankan oleh kommponen eksekutif dan dilaksanakan oleh birokrasi dari eksekutif tersebut, sehingga sering disebut juga birokrasi penegakkan hukum yang terdiri dari hakim, jaksa dan polisi. (Satjipto Rahardjo, 2000; 181).

Berdasarkan uraian diatas maka dapat ditarik suatu permasalahan antara lain : Sejauh mana kesadaran hukum masyarakat dalam berlalulintas dan Bagaimana pelaksanaan penegakan hukum Undang Undang No 14 tahun 1992 tentang Undang Undang Lalulintas dan Angkutan Jalan.

\section{B. PEMBAHASAN}

B.1. Kesadaran Hukum dan Indikator Kurangnya Kesadaran Hukum
Masalah kesadaran hukum masyarakat dalam kaitannya dengan disiplin di jalan raya, merupakan persoalan yang rumit. Kesadaran dapat diartikan sebagai suatu penilaian terhadap suatu realita hukum dengan hukum yang diharapkan. Setiap masyarakat sebenarnya telah mempunyai kesadaran hukum. Oleh karena itu tidak ada warga masyarakat yang tidak ingin hidup dalam keadaan teratur. Masalahnya sampai seberapa jauh tingkat kesadaran hukum masyarakat yang bersangkutan, ada yang hanya mengetahui hukum sebagai peraturan, ada pula yang berperilaku sesuai dengan hukum. Yang terakhir ini merupakan indicator adanya kesadaran hukum yang tingggi dan sekaligus dapat dianggap orang yang disiplin terhadap hukum, oleh karena itu mematuhi hukum dalam kenyataan.

Menurut Soerjono Soekanto (1982; 54) menyatakan kepatuhan terhadap hukum ditentukan oleh factor pengetahuan tentang hukum, pengetahuan isi hukum, sikap terhadap peraturan dan perilaku yang sesuai dengan peraturan. Suatu masyarakat akan patuh pada hukum didasarakan antara lain; (1) karena adanya doktriner untuk berbuat demikian, sejak kecil manusia dididik untuk mematuhi kaidah yang berlaku dalam masyarakat sebagai bagian dari unsure kebudayaan. Melalui proses sosialisasi manusia dididik untuk mengenal, mengetahui serta mematuhi kaidah tersebut (2) karena proses kebiasaan, Setiap hari dialami, sehingga menjadi kebiasaan untuk mematuhinya secara bersama (3) adanya kecenderungan manusia hidup teratur. Ide 
teratur bagi seseorang belum tentu teratur bagi orang lain. Karena itu perlu adanya kaidah yang mengatur bersama yang bersifat obyektif (4) kepatuhan terhadap hukum sebagai salah satu sarana untuk mengadakan identifikasi terhadap kelompok.

Realita dalam masyarakat menunjukan kesadaran hukum berlalulintas masih tipis. Hal ini nampak pada pemakai jalan yang sering malakukan pelanggaran baik disengaja maupun tidak disengaja karena kelalaian. Pengendara kendaraan bermotor begitu saja tancap gas walaupun melihat lampu kuning menyala yang seharusnya ia mengurangi kecepatan, tidak menggunakan helm saat mengendarai sepeda motor dan mengendarai sepeda motor ataupun mobil dengan tidak memberi kesempatan kepada penyeberang jalan (pejalan kaki) dan sebagainya.

Realitas diatas membuktikan bahwa kesadaran hukum pengendara sangat diperlukan untuk mewujudkan tertib berlalu lintas. Menurut Jaksa Agung Sukarton pada waktu itu dalam bukunya "Penegakan Hukum di Negara Pancasila" dijelaskan kesadaran hukum mempunyai 2 (dua) pengertian yaitu : Kesadaran untuk mematuhi ketentuan ketentuan hukum dan kesadaran untuk turut serta memikul tanggungjawab bersama untuk menegakakan hukum. (Sukarton, 1986, 16). Kajian sosiologi hukum terhadap kepatuhan hukum pada dasarnya melibatkan dua variabel, masing - masing; hukum dan manusia yang menjadi obyek pengaturan hukum tersebut. Dengan demikian, maka kepatuhan terhadap hukum tidak hanya dilihat sebagai fungsi peraturan hukum, melainkan juga fungsi manusia yang menjadi asasaran pengaturan. Kepatuhan hukum tidak hanya dijelaskan dari kehaditran hukum, melainnkan juga dari kesediaan manusia untuk mematuhinya. (Satjipto Rahardjo, 2004; 188)

Persoalan kesadaran hukum berlalulintas memerlukan penyelesaian berstrategi jangka panjang; bukan mengutamakan pemaksaan dengan penerapan sanksi-sanksi yang tegas, melainkan mengutamakan usaha mensosialisasi "hukum baru" (baca hukum Negara yang dipopulerkan denagn sebutan hukum nasional) melalui aktivitas-aktivitas berencana yang disebut penyuluhan. Aktivitas seperti ini tentulah bertujuan tunggal, yaitu terbangkitnya kesadaran hukum yang baru; penyuluhan-penyuluhan yang dilakukan dewasa ini, tidak hanya oleh aparat-aparat pemerintah saja, sudah semestinya kalau dilakukan tidak hanya dengan kesan hanya hendak mengkabarkan telah diundangkannya hukum - hukum baru dalam masyarakat, yang oleh sebab itu harus ditaati. Penyuluhan harus menjangkau tujuan -tujuan yang lebih dari itu. (Soetandyo, 2002, 366-367).

Ide tentang kesadaran hukum warga masyarakat sebagi dasar sahnya hukum positif tertulis ditemukan dalan ajaran ajaran tentang rechtsgefuhl atau rechtsbewustzijn yang intinya adalah, bahwa tidak ada hukum yang mengikat warga warga masyarakat kecuali atas dasar kesadaran hukumnya. Hal tersebut merupakan salah asatu aspek dari kesadaran hukum, aspek lainnya adalah bahwa 
kesadaran hukum sering kali dikaitkan dengan pentaatan hukum, pembentukan hukm dan efektivitas hukum.

Kesadaran hukum berkaitan pula dengan efektivitas hukum dan wibawa hukum. Salah satu segi pembicaraan mengenai efektivitas hukum sering kali dikaitkan dengan pengaruh hukum dimasyarakat. Inti dari pengaruh hukum terhadap masyarakat adalah pola perilaku warga masyarakat yang sesuai dengan hukum yang berlaku atau yang telah diputuskan. Bila hal ini dikaitkan dengan indicator kesadaran hukum yang terdiri dari empat (4) indicator yang masing - masing merupakan suatu tahapan bagi tahapan berikutnya yaitu yang dikemukakan oleh Soerjono Soekanto $(1982 ; 140)$ antara lain (1) pengetahuan hukum, yaitu pengetahuan seseorang mengenai beberapa perilaku tertentu yang diatur oleh hukum (2) pemahaman hukum berarti sejumlah informasi yang dimiliki seseorang mengenai isi peraturan dari suatu hukum tertentu (3) Sikap hukum yaitu suatu kecenderungan untuk menerima hukum karena adanya penghargaan terhadap hukum sebagai sesuatu yang bermanfaat atau menguntungkan jika hukum itu ditaati (4) pola perilaku hukum.

Sebagai warga masyarakat, hendaknya kita mempunyai kesadaran hukum yang tinggi melalui disiplin yang tinggi. Seseorang yang mempunyai disiplin yang tinggi akan selalu bersikap dan berperilaku sesuai dengan ketentuan - ketentuan yang dianggap baik oleh masyarakat dan ia akan selalu mendukung masalah - masalah kepentingan umum. Oleh sebab itu, setiap warga masyarakat yang selalu disiplin selalu berperilaku tertib dan teratur. Sebaliknya, apabila warga masyarakat itu tidak berdisiplin dan berperilaku menurut kehendaknya sendiri, maka akan merusak ketentraman, ketertiban dan stabilitas sosial, yang pada akhirnya akan merugikan masyarakat secara keseluruhan. (Marmosudhono Sukarton, 1982; 140)

Oleh karena kesadaran hukum merupakan sesuatu yang bersifat abstrak, maka untuk mengetahui kesadaran hukum dalam masyarakat dapat dilihat dengan melalui indicator - indicator yang ada dalam masyarakat, yang berupa pelanggaran pelanggaran terhadap aturan hukum yang berlaku. Sebenaranya kesadaran hukum merupakan kontruksi yang tidak dapat dikenal atau diukur secara sistematis maupun matematik. Untuk mengetahui ada tidaknya atau tebal tipisnya kesadaran hukum yang bersifat abstrak ini harus terlebih dahulu dioperasionalkan dalam bentuk yang lebih konkrit, baru dapat dievaluasi bahwa pada diri seseorang itu ada kesadaran hukum atau tidak. (Ari Purmadi, 1990; 102)

Rumusan operasional dari kesadaran hukum yang abstrak diwujudkan dalam bentuk variabel yang empiric yang mempunyai fungsi sebagai indicator. Kesadaran hukum berlalulintas, indikatornya dapat dilihat dalam pentaatan pemakaian jalan secara sukarela pada hak dan kewajiban yang timbul dari aturan lalulintas. Apakah tidak melakukan pelanggaran misalnya apakah pengemudi mempunyai Surat Ijin Mengemudi (SIM), apakah membawa Surat Tanda Nomor Kendaraan (STNK), apakah pengendara sepeda motor menggunakan helm, apakah kendaraan yang digunakan 
lengkap perlengkapannya, bagi pejalan kaki apakah sudah melewati tempat yang sudah disediakan, apakah telah menyeberang pada tempat yang sudah disediakan dan lain-lainnya.

\section{B.2. Penegakkan Hukum Dan Faktor-Faktor}

\section{Yang Mempengaruhinya.}

Hukum merupakan salah satu bentuk karya manusia tertentu dalam rangka mengatur kehidupan manusia itu sendiri. Oleh karena itu, kita akan dapat menemukannya dalam berbagai macam bentuk hukum. Diantara bentuk-bentuk hukum tersebut, yang paling tegas dan terinci mengutarakan isinya adalah dalam bentuk tertulis atau dlam istilah lain adalah bentuk system hukum formal. Yang di,maksud dengan formal disini adalah hukum yang dibentuk oleh suatu lembaga atau pejabat yang berwenang membentuk hukum formal tersebut. Misalnya contoh di Indonesia adalah undang-undang yang dibentuk oleh Presiden dengan Dewan Perwakilan Rakyat. (Otje Salman, Anthon F. Susanto, 2004; 82). Negara modern menciptakan mesin kekuasaan khusus untuk membuat hukum dan menyiapkan pula kelengkapan untuk mendukungnya, seperti polisi, jaksa, dan sistem peradilan pada umumnya. (Satjipto Rahardjo, 2004; 186).

Dengan ancaman sanksi berat diharapkan orang menjadi takut melanggar lampu setopan atau rambu-rambu lalulintas lainnya. Demikian juga mereka yang tidak mempunyai SIM tidak akan berani lagi mengendaraai kendaraan di jalan raya. Pendek kata menerapkan sansi berat merupakan sanksi berat merupakan cara untuk memacu masyarakat agar dapat berperan serta dalam proses penegakkan Undang-undang No 1 tahun 1992.
Hukum berfungsi sebagai perlindungan kepentingan manusia. Agar kepentingan manusia terlindungi, hukum harus dilaksanakan. Pelaksanaan hukum dapat bearlangsung secara normal, damai tetapi dapat juga terjadi karena pelanggaran hukum. Dalam hal ini hukum yang telah dilanggar harus ditegakkan. Melalui penegakan hukum inilah hukum itu menjadi kenyataan. Dalam penegakan hukum ada tiga unsure yang harus selalu diperhatikan, yaitu; kepastian hukum (rechtssicherheit), kemanfaatan (zweck massigkeit), dan keadilan (gerechtigkeit). Hukum harus dilaksanakan dan ditegakkan. Setiap orang mengharapkan dapat diterapkannya hukum dalam hal terjadi peristiwa. (Sudikno Mertokusumo, 1999; 145)

Salah satu fungsi hukum sebagai sarana pengendali sosial sudah tidak dapat lagi mengandalkan-penuhnya pada kemampuan peraturan-peraturan hukum formal. Bertolak dari persoalan ini, Satjipto Rahardjo pernah mengajukan pertanyaan menggelitik, bahwa "apakah nilai-nilai hukum yang kita miliki cukup mampu untuk mengatur kehidupan masyarakat Indonesia sekarang yang jauh lebih rumit dari pada sediakala?" Pertanyaan seperti ini sebagai isyarat bahwa sudah saatnya studi hukum perlu dikaitkan dengan bidang-bidang keilmuan lain yang terletak di luar lapangan ilmu hukum seperti antropologi, sosiologi, ilmu politik dan sebagainya. (Esmi Warassih, 2005; 8)

Pokok pemikiran bahwa Undangundang Lalulintas sejalan dengan pemikiran 
Roscoe Pound berkisar pada tema bahwa hukum bukanlah suatu keadaan yang statis melainkan suatu proses. Suatu pembentukan hukum, interprestasinya maupun penerapannya hendaknya dihubungkan dengan fakta - fakta sosial. Pound sangat menekankan pada efektivitas bekerjanya hukum dan untuk itu ia sangat mementingkan beroperasinya hukum dalam masyarakat. Oleh karena itu Pound membedakan pengertian law in books disatu pihak dan law in action dilain pihak. Perbedaan ini dapat diterapkan pada seluruh bidang hukum, baik hukum substantif maupun hukum ajektif.(Otje S. dan Anthon F. Susanto, 2004; 35)

Dapat dikatakan bahwa penegakkan hukum bukanlah semata - mata pelaksanaan peraturan perundang - undangan, melainkan kegiatan menyerasikan hubungan nilai - nilai yang dijabarkan di dalam kaidah - kaidah hukum yang mantap. Pelaksanaan tersebut berkaitan erat dengan efektifnya hukum ysng berlaku dimasyarakat

Hukum seringkali tidak efektif mengatur hubungan atau keserasian dan keteraturan dalam mengatur manusia dlam kehidupan bermasyarakat. Ketidak efektifan hukum dapat disebabkan oleh factor - factor manusia sebagai perencana, sebagai pelaksana, fasilaitas atau sarana yang mendukung penegakan hukum. Hal ini tidak hanya disebabkan ketidakpahaman aparatur, ketidakpatuhan masyarakat, akan tetapi berkaitan dengan kompleksitasnya permasalahan dengan pelaksanaan hukum. Hukum berlaku secara efektif apabila substansi hukum saling berkaitan, Substansi - substansi dimaksud adalah yang menyangkut aspek filosofis, yuridis dan sosiologis.

Proses kerjanya aturan atau hukum yang telah diciptakan dalam masyarakat memerlukan beberapa tahapan. Tahapan tersebut diantaranya adalah; harus ada pejabat yang ditetapkan dalam peraturan hukum, harus ada orang - orang yang melaksanakan peraturan itu dan mengetahui adanya peraturan tersebut, dan adanya kemauan dari orang - orang tersebut untuk melaksanakan, dengan kata lain proses penegakan hukum dapat berjalan dengan baik bukan semata mata peraturan perundang - undangannya melainkan adanya dukungan sikap, semangat, dan dedikasi dari pelaksana dari hukum tersebut.

Penegakan hukum adalah kata Indonesia untuk Law enforcement. Dalam bahasa Belanda dikenal rechtstoepassing dan rechtshandhaving. Pemikiran yang dominant disini mengatakan, bahwa penegakan hukum adalah suatu proses logis yang mengikuti kehadiran suatu peraturan hukum. Apa yang harus terjadi menyusul kehadiran peraturan hukum hampir sepenuhnya terjadi melalui pengolahan logika. Logika menjadi kredo dalam penegakan hukm.

Penegakan hukum dapa juga dilihat sebagai proses yang melibatkan manusia didalamnya. Sosiologi Hukum melihat penegakan hukum dengan pengamatan yang demikian itu sesuai dengan tradisi empiriknya, maka dalam pengamatan terhadap kenyataan penegakan hukum, factor manusia sangat terlibat dalam usaha penegakan hukum tersebut. (Rahardjo, 2004, 174-175). 
Masalah pokok yang mempengaruhi penegakkan hukum terletak pada beberapa foktor, factor - factor tersebut adalah; (1) factor hukumnya sendiri, yaitu undang - undang (2) factor penegakkan hukum, yaitu pihak - pihak yang membentuk maupun yang menerapkan hukum (3) factor sarana atau fasilitas yang mendukung penegakkan hukum (4) factor masyarakat, yaitu lingkungn dimana hukum tersebut berlaku dan diterapkan (5) factor kebudayaan, yaitu sebagai hasil karya, cipta dan rasa yang didasarkan pada karsa manusia di dalam pergaulan hidup. (Soerjono Soekanto, $1983 ; 5)$

Lawrence M. Friedman (1975; 27) dengan teori Legal System menyatakan, untuk kepentingan menganalisis system hukum terdapat tiga (3) komponen yaitu; (a) komponen substansi (Substance of Legal System), yaitu hasil kerja actual yang diterbitkan oleh system hukum yang berupa peraturan - peraturan, doktrin - doktrin, keputusan - keputusan yang digunakan baik oleh pihak yang mengatur maupun yang diatur. (b) Komponen Struktural (Structure of Legal System), yaitu kelembagaan yang meruipakan bagian - bagian yang bergerak di dalam suatu mekanisme yang diciptakan oleh system hukum dengan berbagai fungsinya guna mendukung bekerjannya system hukum tersebut. (c) Komponen Kultur public dan nilai - nilai (Legal Culture), yaitu komponen yang akan menentukan penegakkan hukum, kapan, kenapa dan di mana seperangkat nilai nilai dan sikap serta norma - norma itu akan dilaksanakan

\section{KESIMPULAN}

Maksud dikeluarkannya Undang Undang
No 14 tahun 1992 yaitu untuk meningkatkan kesadaran dalam disiplin berlalulintas. Disiplin berlalulintas seharusnya tumbuh dan berkembang dari kesadaran setiap pengguna jalan raya, bukan karena paksaan ataupun dengan memperberat sanksi atau denda terhadap para pelanggar.

Dalam proses penegakan hukum selalu melibatkan warga masyarakat berarti masyarakat ikut mengontrol cara bekerjannya lembaga - lembaga penegak hukum seperti jaksa, hakim, polisi dan pengacara agar menjalankan fungsi dan perannya sesuai dengan yang telah digariskan hukum.

\section{DAFTAR BACAAN}

\section{Buku}

Ari Purwadi, 1990, Pembentukan Sikap Patuh Warga Masyarakat kepada Peraturan Hukum Melalui Penyuluhan Hukum, (Majalah Fakultas Hukum Universitas Airlangga No; 2, tahun V, Maret, April, 1)

Benny Harman, 1993, Undang Undang dan Kepatuhan Masyarakat dalam Undang Undang Lalulintas dan Angkutan Jalan Aneka Pandangan dan Opini, Pustaka Sinar Harapan, Jakarta.

Esmi Warassih, 2005,Pranata Hukum Sebuah telaah Sosiologis, PT Suryandaru Utama, Semarang.

Marmosudhono Soekarton, 1982, Penegakan Hukum di Negara Pancasila, PT Pustaka Kartini, Jakarta.

Otje Salman dan Anthon F. Susanto, 2004, Beberapa Aspek Sosiologi Hukum, PT Alumni, Bandung.

Robert Palandeng,Hernowo Wibowo, Bien Pasaribu, 1993, Undang Undang Lalulintas dan Angkutan Jalan Aneka Pandangan dan Opini, Pustaka Sinar Harapan, Jakarta.

Satjipto Rahardjo, 2004, Sosiologi Hukum Perkembangan Metode dan Pilihan Masalah, Universitas Muhamadiyah Surakarta, Surakarta.

Satjipto Rahardjo, 2000, Ilmu Hukum, Citra 


\section{JURNAL JENDELA HUKUM}

Aditya Bakti Bandung

Sudikno Mertokusumo, 1999, Mengenal

Hukum Suatu Pengantar, Liberty,

Yogyakarta.

Suryono Soekanto, 1985, Kesadaran Hukum

Dan Kepatuhan Hukum, Cv Rajawali, Jakarta.

Soerjono Soekanto, 1983, Faktor - factor yang Mempengaruhi Penegakkan Hukum, CV. Rajawali, Jakarta

Soetandyo Wignjosoebroto, 2002, Hukum Paradigma, Metode dan Dinamika Masalahnya,ELSAM, Jakarta. 